\title{
Калашникова Н.А.
}

\section{Применение критического дискурс-анализа в контексте} развития навыков критического мышления

\author{
Kalashnikova N.A. \\ Application of critical discourse analysis in the context \\ of the development of critical thinking skills
}

В настоящей работе обозначена специфика применения критического дискурс-анализа в контексте развития навыков критического мышления, рассмотрены различные концепции дискурс-анализа, представлена трехмерная модель дискурс-анализа Н. Фэрклоу, изложен алгоритм ее использования

Ключевые слова: дискурс, дискурс-анализ, критический дискурс-анализ

\section{Калашникова Нина Александровна}

Кандидат философских наук, доцент

Волгоградский государственный университет

г. Волгоград, пр-т Университетский, 100

\begin{abstract}
In this paper denotes the specific application of critical discourse analysis in the context of the development of critical thinking skills, consider different concepts of discourse analysis, shows a three-dimensional model of discourse analysis $N$. Ferklou, the algorithm of its use
\end{abstract}

Key words: discourse, discourse analysis, critical discourse analysis

\author{
Kalashnikova Nina Aleksandrovna \\ Candidate of Philosophical Sciences, \\ Associate Professor \\ Volgograd state university \\ Volgograd, Universitetsky ave., 100
}

Дискурс-анализ - научное направление, возникшее на стыке психологии, философии, лингвистики и социологии., исследующее дискурс различных социальных групп, отраженный в речи индивидов [3., с.101].

Одной из концепций дискурс-анализа является критический дискурс-анализ. «Для специалиста в области критического дискурс-анализа, дискурс - это форма социальной практики, которая одновременно и созидает социальный мир, и одновременно созидаема посредством других социальных практик»[8, с. 101]. Занимаясь выявлением властных отношений в дискурсе, представители критического дискурс-анализа рассматривают власть как производительную силу,возникающую в результате усвоения и признания некоторого типа языка участниками социальных взаимодействий.

Идейно-теоретическими источниками критического дискурс-анализа являются работы философов и ученых, внесших значительный вклад в изучение и критическое осмысление дискурса. К таким авторам относятся: М. Бахтин, А. Грамши, Л. Альтюссер, М. Фуко, Р. Барт, П.Бурдье и другие [6]. 
Помимо междисциплинарной специфики, важной характеристикой критического дискурс-анализа является принцип «критики», а именно: «критический дискурс-анализ определился не столько как направление дискурсивных исследований, сколько как критический ракурс любых исследований, связанных с ролью языка в передаче знания» [4]. Именно этот потенциал критического дискурс- анализа может быть применен для развития навыков критического мышления.

Как правило, критическое мышление представляется неким способом проверки соответствия информации требованиям достоверности, точности, логической корректности, и, в конечном итоге, определения ее ценности. Критическое мышление помогает давать панорамную (с учетом альтернативных точек зрения) оценку события, видеть причинно-следственные связи, изменять свою позицию на основе аргументов. Применение критического-дискурс анализа, в свою очередь, позволяет идентифицировать виды манипулятивных практик, связанных с идеологическими и властно-политическими структурами языка, что, несомненно, открывает дополнительные возможности для развития критического мышления в направлении повышения устойчивости к различного рода манипуляциям.

Одним из наиболее известных представителей критического дискурс-анализа считается Н. Фэрклоу [2, с. 132], который определяет критический дискурсанализ как подход, систематически исследующий едва заметные отношения причинности и детерминированности между дискурсивными практиками, событиями, текстами, а также более широкими социальными и культурными структурами,отношениями и процессами. Н. Фэрклоу подчеркивает значимость текстового уровня в дискурс-анализе и критикует недостаточное внимание, которое ему уделяют в социальных науках, несмотря на заметный «поворот к лингвистике». Н. Фэрклоу называет критический дискурс-анализ «одной из стратегий анализа общественных отношений и структуры, наряду с этнографией или институциональным анализом» [1,c. 2].

Однако само понятие «критический дискурс-анализ» до сих пор не имеет однозначного определения в научной литературе и используется как для обозначения подхода, разработанного Н. Фэрклоу, так и для более широкого научного течения, включающего ряд других подходов [5, с. 48].

Согласно Н. Фэрклоу, в критическом дискурс-анализе основополагающими понятиями являются - «коммуникативное событие» (отдельный случай использования языка) и «дискурс-строй» (конфигурация всех типов дискурсов, которые используются в каком-либо социальном институте или социальной области) [2, с. 145]. Коммуникативное событие содержит три измерения: текст (речь, письмо, визуальное изображение или их сочетание); дискурсивная практика, которая включает производство и воспроизводство текстов и разговоров, и социальная практика. Типы дискурсов состоят из стилей (дискурсов) и жанров [3, с. 73]. Жанр - особое использование языка, которое составляет часть отдельной социальной практики.

Для того, чтобы произвести критический дискурс-анализ согласно трехмерной модели Н. Фэркло, нужно: а) дать обзор дискурсивной практики 
коммуникативного события, определить тип текста; степень интертекстуальности, т.е. присутствия в анализируемом тексте других текстов, степень интердискурсивности, т.е. артикуляции различных дискурсов и жанров в одном коммуникативном событии; б) произвести анализ текста и его конкретных лингвистических особенностей, определить степень транзитивности, т.е. степень соотношения между текстом, социальной практикой, иллюстрируемой этим текстом, и его реципиентом, проявляющаяся, в том числе, в таких грамматических особенностях, как степень номинализации и т.п. , модальность - субъективная или объективная, оценка - положительная или отрицательная); в) произвести анализ социальной матрицы дискурса - широкого социального контекста, в котором существуют конкретные коммуникативные события [7, с.149].

\section{Список используемых источников:}

1. Fairclough N. Analyzing Discourse. Textual Analysis for Social Research. L.; N. Y.: Routledge Taylor \& Francis Groupe, 2003. 270 p.

2. Fairclough N. Critical Discourse Analysis. Boston: Addison Wesley Publishing Company, 1995.266 p.

3. Иванов А.Г, Михалькова Е.В., Школенко А.С.Терминологическое обоснование понятий «идея», «ценность», «норма»в критическом дискурс-анализе // Вестник Тюменского государственного университета. Сер. Философия.№10. 2012. С. 101-105.

4. Кравченко Н.К. Практическая дискурсология: школы, методы, методики современного дискурсанализа. Научно-практическое пособие. Луцьк: Волиньполіграф, 2012. 251 c.

5. Пугина Е.И. Применение критического дискурс-анализа в исследованиях новых религиозных движений // Вестник Нижегородского университета им. Н.И. Лобачевского. Серия Социальные науки, 2011 № 4(24). C. 48-52.

6. Русакова О.Ф., Ишменев Е.В. Критический дискурс-анализ // Современные теории дискурса: мультидисциплинарный анализ (Серия «Дискурсология»). Екатеринбург: Издательский Дом «ДискурсПu», 2006. С. 36-48.

7.Тетерин А.Е. Применение качественных методов в политологическом исследовании (на примере критического дискурс-анализа Н. Фэркло) // Полис. № 5. 2011. С. 145-150.

8.Филлипс Л., Йоргенсен М. В. Дискурс-анализ. Теория и метод. М.: Гуманитарный центр, 2008. 352 c. 11.Ivanov A.G, Mikhalkova E.V., Shkolenko A.S.Terminologicheskoye justification of the concepts "idea", "value", "norm" in critical a discourse analysis//the Bulletin of the Tyumen state university. It is gray. Философия. № 10. 2012. P. 101-105.

12.Kravchenko N. K. Practical diskursologiya: schools, methods, techniques modern discourse analysis. Scientific and practical grant. Lutsk: Volinpol_graf, 2012. 251 pages.

URL: http://discourse.com.ua/diskurs-analiz/kriticheskij-diskurs-analiz/

13.Pugina E.I. Application critical a discourse analysis in researches of new religious movements // the Bulletin of the Nizhny Novgorod university of N. I. Lobachevsky. Series Social sciences, 2011. No. 4(24). P. 48-52.

14.Rusakova O. F., Ishmenev E.V. Kritichesky discourse analysis//Modern theories of a discourse: the multidisciplinary analysis (Diskursologiya Series). Yekaterinburg: Diskurs-Pi publishing House, 2006. P. 36-48. 15.Teterin A.E. Application of qualitative methods in politological research (on the example of critical N. Ferklo's discourse analysis) // the Policy. No. 5. 2011. P. 145-150.

16.Phillips L., Jorgensen M. W. Discourse analysis. Theory and method. M.: Humanitarian center, 2008. 352 p.

(c) 2016, Калашникова Н.A.

Применение критического дискурс-анализа в контексте развития навыков критического мышления
(C) 2016, Kalashnikova N.A.

Application of critical discourse analysis in the context of the development of critical thinking skills 